\title{
Urban fire risk: Evaluation and emergency planning
}

\author{
Tiago Miguel Ferreira ${ }^{\mathrm{a}, *}$, Romeu Vicente ${ }^{\mathrm{a}, 1}$, José António Raimundo Mendes da Silva ${ }^{\mathrm{b}, 2}$, \\ Humberto Varum ${ }^{\mathrm{c}, 3}$, Aníbal Costa ${ }^{\mathrm{a}}$, Rui Maio ${ }^{\mathrm{a}, 4}$ \\ a RISCO - Department of Civil Engineering, University of Aveiro, Campus Universitário de Santiago, 3810-193 Aveiro, Portugal \\ ${ }^{\mathrm{b}}$ LAETA - Department of Civil Engineering, University of Coimbra, Rua Luís Reis Santos - Pólo II da Universidade, 3030-788 Coimbra, Portugal \\ ${ }^{\mathrm{c}}$ CONSTRUCT - Department of Civil Engineering - Structural Division, Faculty of Engineering of the University of Porto, Rua Dr. Roberto Frias, $4200-465$ \\ Porto, Portugal
}

\section{A R T I C L E I N F O}

\section{Article history:}

Received 26 November 2014

Accepted 21 January 2016

Available online 7 July 2016

\section{Keywords:}

Old city centres

Fire risk

ARICA method

Emergency planning

Old buildings

\begin{abstract}
A B S T R A C $T$
The management, prevention and mitigation of urban risks are assumed as priority actions within the framework of any rehabilitation and requalification process at the urban scale, particularly in the case of the rehabilitation and refurbishment of old city centres. In the most specific domain of urban safety, seismic and fire risk, which can cause serious consequences, are part of the collective memory of several communities and must be inevitably highlighted. The severity of the resulting damages is a more than valid reason to strongly value prevention, planning and mitigation strategies, limiting their consequences and guaranteeing permanent improvement actions. In the view of the abovementioned, and in the scope of a research project carried out, a new urban fire risk assessment methodology was developed and applied to the old city centre of Seixal. This simplified methodology is based on a preestablished method designated ARICA. Over 500 buildings were assessed using this methodology, and the results were spatially analysed using an integrated geographical information system tool (GIS). It is worth noting that the integration of the risk results into a GIS platform is a valuable step towards the risk mitigation at a urban scale, allowing city councils or regional authorities to plan interventions on the basis of a global spatial view of the site under analysis leading to more accurate and comprehensive risk mitigation strategies that support the requirements of safety and emergency planning in case of urban fire.
\end{abstract}

(C) 2016 Elsevier Masson SAS. All rights reserved.

\section{Introduction}

\subsection{Framework}

Old city centres are particular areas of vital importance due to their valuable historical, architectural, cultural and social heritage, which should be preserved and constantly valued. In this sense, it is essential that institutions responsible for safeguarding this heritage and the population who benefit from it, join forces and work together on the prevention of fire risk within these areas [1].

The unique features of old city centres and its building stock are clearly distinct from recent urban areas, favouring the ignition

\footnotetext{
* Corresponding author. Tel.: +00351 234370 04; fax: +00351 234370094.

E-mail addresses: tmferreira@ua.pt (T.M. Ferreira),romvic@ua.pt (R. Vicente), raimundo@dec.uc.pt (J.A. Raimundo Mendes da Silva), hvarum@fe.up.pt (H. Varum), agc@ua.pt (A. Costa), ruiamaio@ua.pt (R. Maio).

1 Tel.: +00351234370 04; fax: +00351234370 094

2 Tel.: +00351239797 206; fax: +00351239832969.

3 Tel.: +00351220 414 882; fax: +1446.

4 Tel.: +00351234370 04; fax: +00351234370094.
}

and propagation of a fire. Several factors have been identified as potential contributors for increasing fire risk in these areas: combustible materials present in traditional buildings, the high density of buildings in old city centres with narrow unobstructed street widths, the wall sharing between adjacent buildings, the inadequate adaptation of buildings to non-residential purposes, the proliferation of unoccupied or derelict buildings frequently storing large amounts of combustible materials and mainly, the existence of old electrical installations with lack of maintenance, which is one of the main causes of fire risk of old building stock [2].

Throughout world history, there are multiple devastating fire examples with catastrophic consequences in both economy and heritage. The 1666 great fire of London, and the 1871 fire of Chicago, are two of the most significant urban fire events, leading to the nearly collapse of both cities and to human loss scale with no precedents in history. In Portugal, the 1988 Chiado fire, affecting this important warehouse and commercial area of Lisbon (see Fig. 1), remains as one of the most marking fire event in the country, leading inclusively to the creation of the first Portuguese Ministerial Order No. 426/89 of 6th December, entirely dedicated to this matter [3]. Although, no other similar or comparable event has occurred, 

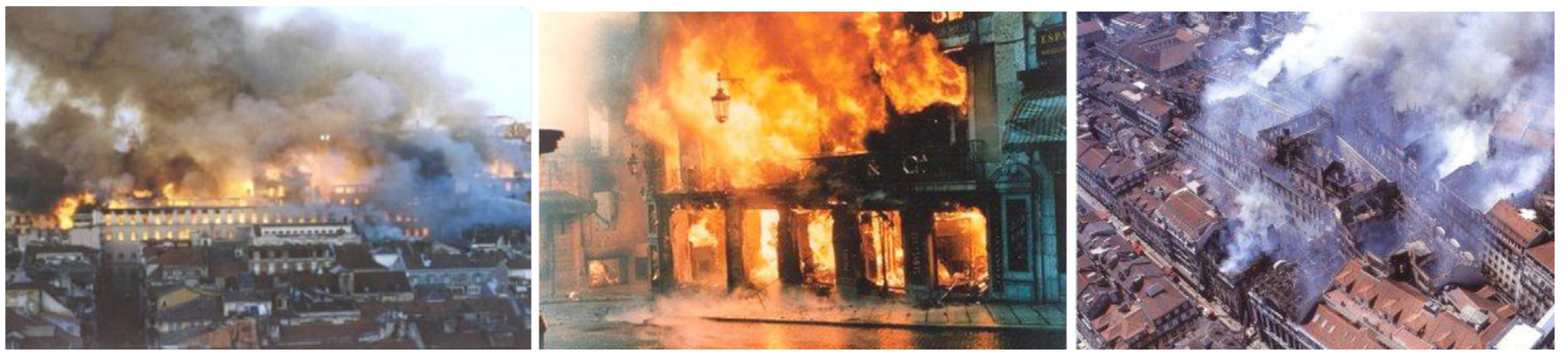

Fig. 1. Chiado fire during both propagation and extinction phase $[8,9]$.

fire risk in old city centres is recognised by citizens and responsible entities as a serious problem. In 2010, Coelho has developed a comprehensive work on building conservation and rehabilitation from the point of view of fire safety, identifying the most common issues found in our building stock and suggesting some solution to overcome those deficiencies [4]. Although fire risk assessment methodologies continue at an early stage of development in respect to large-scale assessment an important contribution was recently given by Magalhães [5] which may enhance development and bring attention to fire safety in buildings within urban areas, through the development of an IT tool designated FIREcheck, geared towards the organisation, planning and data storage of fire surveying and inspection work of buildings. Moreover, a handbook containing guidelines and procedures to carry out during fire safety surveying work has also been developed by [5]. This tool was comprehensively reviewed and optimised by Barral [6] to incorporate the self-protection practices and measures defined in the latest national fire safety code [7].

\subsection{Research aims}

The main goal of this research work is focused on developing a large-scale supporting tool for emergency planning directed mainly towards to old city centres. In a first phase, the Seixal case study allowed to identify and collect the main fire risk vulnerability sources and then, in a second phase, to use these data as input for the development and application of the new methodology to assess urban fire risk. The first phase of identification and data collection was performed through a group of coordinated field inspections identifying the principal safety factors against fire risk in historical buildings, which were stored in a linked database used in a GIS tool environment.

\section{Method of research: fire risk index}

Fire risk assessment methodologies currently available are scarce and the great majority of them were developed exclusively for the evaluation of single and recently-built buildings, therefore being unsuitable for application to old masonry buildings or at larger scales. Even though, four different existing methodologies should be listed due to their characteristics, which can be in a broad sense approximated to the old city centres reality: the Gretener method; the FRAME method; the FRIM method and the ARICA method [10]. All the referred methodologies have their applicability scale as a common denominator, which is directed to single buildings or at most to building aggregate assessment. Nevertheless, ARICA method presents a clear advantage when compared with the remaining ones, it is much more flexible in terms of methodological formulations allowing that, with some modifications, it can be used to assess either old or recent buildings. This is the whole point of developing an expeditious methodology on the same base as the scoring
Table 1

Global factors, sub-factors and partial factors definition.

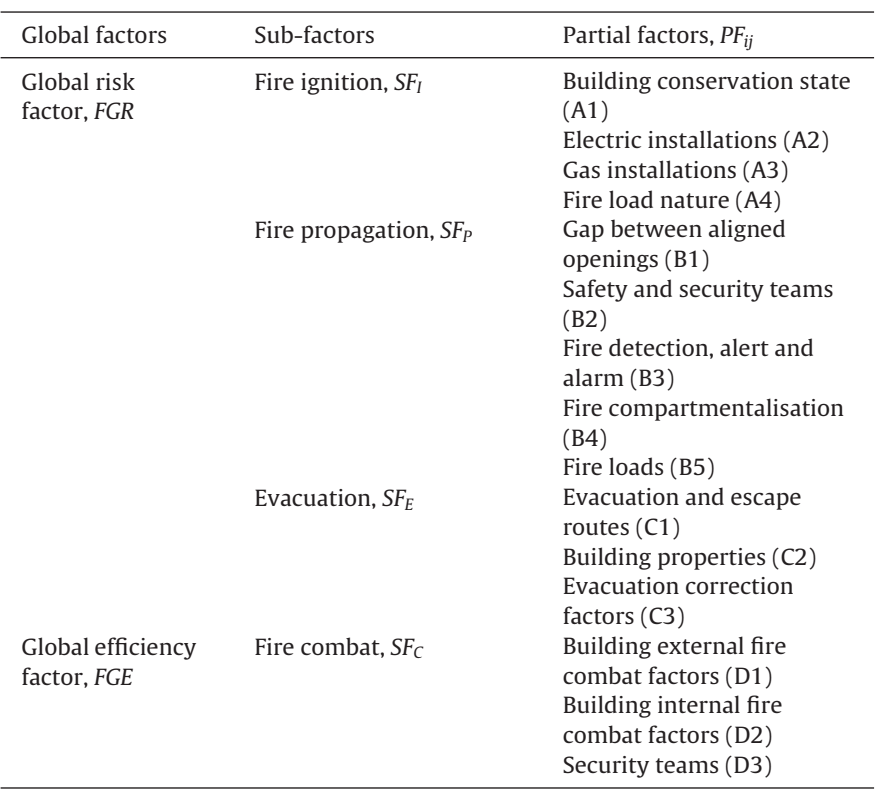

methodology developed by Vicente for the seismic vulnerability assessment of old masonry buildings at the urban scale [11], which is essentially based in qualitative criteria. Aiming the mentioned goals, a new simplified proposal has been developed with basis on the same principles of the original ARICA method, but this time adapted to the already identified needs.

By exploiting information and research collected during the extensive inspection phase, it was possible to determine the fire risk index, FRI among other indicators. Please note that with this new proposal the authors do not want to disregard the original ARICA method, but assume it as a large-scale reworked and redefined assessment tool, performing an initial and reliable estimation, and highlighting constraints in need of more detailed assessment methodologies. Thus, as the original ARICA method, the new fire risk simplified methodology is based on two main factors: the global risk factor, $F G R$, and the global efficiency factor, FGE (see Table 1). The first is divided in three sub-factors devoted to evaluating the fire ignition phase, the propagation phase and the building evacuation phase. The global efficiency factor, $F G E$, is associated just to one sub-factor evaluating the fire combat phase. The four sub-factors have the same numerical weight in the calculation of the Fire Risk Index (FRI). However, the mentioned sub-factors approach the generality of the aspects related to fire prevention in old masonry buildings, following the whole event from the fire ignition, propagation and evacuation capacity, to fire combat and extinguishing. The sub-factors breakdown into the partial factors that assume numerical values in 
Table 2

Values of the gas installation conditions for partial factor $P F_{A 3}$.

\begin{tabular}{|c|c|c|c|}
\hline & \multicolumn{2}{|c|}{ Gas supplying type and site conditions } & $P F_{A 3}$ \\
\hline Piped gas & - & - & 1.00 \\
\hline Gas reservoir & - & - & 1.10 \\
\hline \multirow[t]{3}{*}{ Gas containers } & $\begin{array}{l}\text { External } \\
\text { installation }\end{array}$ & - & 1.20 \\
\hline & $\begin{array}{l}\text { Internal } \\
\text { installation }\end{array}$ & $\begin{array}{l}\text { Well-ventilated } \\
\text { compartment }\end{array}$ & 1.50 \\
\hline & & $\begin{array}{l}\text { Non-ventilated } \\
\text { compartment }\end{array}$ & 1.80 \\
\hline
\end{tabular}

Table 3

Values of the detection, alert and alarm fire system partial factor $P F_{B 3}$.

\begin{tabular}{ll}
\hline Fire detection, alert and alarm systems & \\
\hline $\begin{array}{l}\text { Code compliance } \\
\text { Equipment/device type }\end{array}$ & $P F_{B 3}$ \\
$\begin{array}{l}\text { Does not require } \\
\text { There is an automatic fire } \\
\text { detection system (automatic } \\
\text { detectors) }\end{array}$ & 0.50 \\
$\quad \begin{array}{l}\text { There is a manual fire detection } \\
\text { system (alarm operator buttons) }\end{array}$ & 0.90 \\
Require & \\
$\begin{array}{l}\text { Equipment in accordance with } \\
\text { fire code requirements }\end{array}$ & 1.00 \\
$\begin{array}{l}\text { There is no manual fire detection } \\
\text { system with alarm operator } \\
\text { buttons }\end{array}$ & 1.20 \\
$\begin{array}{l}\text { There is only a manual fire } \\
\text { detection system, when fire code } \\
\text { requires an automatic fire } \\
\text { detection system as well } \\
\text { There is no automatic fire } \\
\text { detection system }\end{array}$ & 1.80 \\
\end{tabular}

function of the inspection criteria and were defined based on analytical hierarchy process. As interventions in old city centres should be targeted at reducing both the likelihood of fire occurrence and propagation, these two sub-factors, $S F_{I}$ and $S F_{P}$, are affected by aggravating coefficients 1.20 and 1.10 , respectively. The value of each sub-factor is obtained as the sum of all the partial factor values. In turn, these factors evaluate detailed features associated to each sub-factor, such as the state of preservation of the building, electrical and gas installations and the fire load nature, relative to the fire ignition sub-factor, $S F_{I}$.

Below is provided the definition of three of the partial factors specified in Table 1 - PFA3, PFB3, PFC1 and PFD1 -, corresponding to different sub-factors. The values associated to the partial factor $P F_{A 3}$, concerning gas installation and supply, are presented in the following Table 2. Further information regarding the definition and corresponding values of all the other partial factors can be consulted in [12].

The partial factor $P F_{B 3}$ related to detection, alert and alarm fire systems has a great influence over the development and propagation of fire events. The present fire national code [13] establishes two different alarm fire equipment/devices, automatic detectors and alarm operator buttons (manual detectors), being the last naturally far less efficient. The following values in Table 3 were defined to assign the partial factor $P F_{B 3}$. Whenever these detection, alert and alarm equipment is not demanded by the present fire code, one must follow the original ARICA methodology principles [14]. Moreover, the value of this partial factor should be considered equal to 1.00 , having therefore no influence over the fire risk, whenever the existing safety measures meet the fire code requirements.

The partial factor $P F_{C 1}$ considers all features concerning building evacuation conditions and escaping routes, from clear widths of both horizontal and vertical evacuation and escape routes, to windows and doors widths, number of available exits, slope of vertical
Table 4

Coefficient values of the evacuation and escape routes partial factor $P F_{C 1}$.

\begin{tabular}{lc}
\hline Conditions of evacuation and escape routes & $P F_{C 1}$ \\
\hline Widths of corridors/paths and openings lower than & 0.25 \\
$\quad 0.90 \mathrm{~m}$ & 0.25 \\
$\begin{array}{l}\text { Number of exits lower than the minimum regulatory } \\
\text { required }\end{array}$ & 0.25 \\
$\quad \begin{array}{l}\text { Slope of vertical escape routes higher than 45 } \\
\text { Nonexistence of light-signalling emergency systems }\end{array}$ & 0.25 \\
$\quad$ when required & \\
\hline
\end{tabular}

Table 5

Features and values for the accessibility parameter.

\begin{tabular}{lllll}
\hline \multicolumn{4}{l}{ Accessibility and evacuation route conditions } \\
\hline $\begin{array}{l}\text { Height } \\
{[\mathrm{m}]}\end{array}$ & $\begin{array}{l}\text { Width } \\
{[\mathrm{m}]}\end{array}$ & $\begin{array}{l}\text { Clear height } \\
{[\mathrm{m}]}\end{array}$ & Slope $[\%]$ & $\begin{array}{l}\text { Accessibility } \\
\text { parameter } \\
\text { value }\end{array}$ \\
\hline$\leq 9.00$ & $\geq 3.50$ & $\geq 4.00$ & $\leq 15.00$ & 1.00 \\
& $\geq 3.50$ & $\geq 4.00$ & $>15.00$ & 1.50 \\
$>9.00$ & $\geq 6.00$ & $\geq 5.00$ & $\leq 10.00$ & 1.00 \\
& $\geq 6.00$ & $\geq 5.00$ & $>10.00$ & 1.50 \\
\hline
\end{tabular}

Table 6

Features and values for the external fire hydrants parameter.

\begin{tabular}{lll}
\hline Conditions & & \\
\hline Distance from the fire hydrant & $\begin{array}{l}\text { Existence of wall } \\
\text { hydrants }\end{array}$ & $\begin{array}{l}\text { Fire hydrants } \\
\text { parameter value }\end{array}$ \\
\hline$\leq 100 \mathrm{~m}$ & No & 1.00 \\
$>100 \mathrm{~m}$ & Yes & 1.50 \\
& No & 2.00 \\
\hline
\end{tabular}

escape routes and emergency light signage systems, when required. Once again, in comparison to the ARICA methodology [14], the definition of this partial factor comprises a more simplified approach. Thus, to partial factor $P F_{C 1}$ is assigned an initial lower limit value equal to 1.00 , to which eventually added one or more of the following coefficients related to evacuation and escape routes' inherent conditions (in Table 4). It is worth noting that, also in this case, the conditions presented in Table 4 were defined in accordance with the Portuguese fire code [13].

From the last group of partial factors associated to global efficiency, FGE, the definition of the building external fire combat partial factor $P F_{D 1}$ comprises the arithmetic average of the following three parameters: buildings accessibility; external fire hydrants and water supply reliability. Accessibilities are of great importance for fire brigades in tackling fires, since it gives a decisive contribution to fire development and propagation, as already mentioned. In this sense, Table 5 bellow presents the features and conditions needed to evaluate this parameter. In the case of route widths or clear heights below the ranged values listed in Table 5 , this accessibility parameter must be assigned equal to 2.00 , as these are considered two preponderant assessment conditions.

In respect to hydrants assessment parameter, the national fire code demands the existence of fire hydrants at a maximum distance of 30 meters from every building exit. Considering historical city centre mesh one can easily understand that this requirement is unreasonable and thus, the referred maximum distance was assumed in line with this reality, set as 100 meters for the proposed new methodology. The following Table 6 outlines the admissible values referring to external fire hydrants parameter. If first intervention wall hydrants are made available, the value of this parameter is reduced only in the case of distances from fire hydrants higher than 100 meters. 
Table 7

Reference risk factor, $F R_{R}$, determination for different building use type.

\begin{tabular}{lll}
\hline Reference risk factor & Residential & $\begin{array}{l}\text { Service or industrial } \\
\text { spaces, libraries and } \\
\text { archives }\end{array}$ \\
\hline$F R_{R}$ & $0.915+0.25 \times F_{C}{ }^{\mathrm{a}}$ & $1.10+0.25 \times F_{C}^{\mathrm{a}}$
\end{tabular}

a $F_{C}$ is the correction factor and can assume the values of $1.10,1.20$ or 1.30 , for buildings with up to 3 , up to 7 or more than 7 floors, respectively.

The water supply reliability parameter is considered equal to 1.00 , as there is no valid data or information allowing determining its reliability at the necessary moment.

Having explained the previous factors and their definitions, the fire risk index, $F R_{I}$, ranges from 0 to 4 , is given by Eq. (1) that depicts the ratio between the weighted average of all the sub-factors and the reference risk factor, $F R_{R}$, on. This reference risk factor, $F R_{R}$, is determined taking into account the type of building use, since the partial factor relative to the fire load nature $\left(P F_{B 5}\right)$ varies from case to case, as shown in Table 7.

$F R_{I}=\frac{\left(1.20 \times S G_{I}+1.10 \times S F_{P}+S F_{E}+S F_{C}\right) / 4}{F R_{R}}$

As in the ARICA original methodology, the obtained fire risk index, $F R_{I}$, assumes the unit value as the reference value for safety verification. Thus, on the one hand, a fire risk index value higher than the reference value (equal to 1.00) suggests that further interventions are required in order to mitigate its fire risk. On the other hand, a fire risk index value lower than 1.00 means that the building fulfils the Portuguese fire code required minimum conditions, however there is still room for the improvement of some features $[13,15]$. Finally, the normalised fire risk value, $F R_{I}{ }^{*}$, was obtained through the normalisation of the previous $F R_{I}$ value, between 0 and 100 , simplifying the visual interpretation of this output, particularly in a GIS environment. Note that fire risk assessment is a deterministic based approach as a function of the empirical determination of partial factors.

\section{Case study of the old city centre of Seixal, Portugal}

Under the fire risk assessment of the old city centre of Seixal, 504 old masonry buildings were evaluated, spread over a $166,000 \mathrm{~m}^{2}$ area [16]. Trying to optimise both field inspections and data processing time, the case study area was divided into five different zones, according to the typological characteristics of the buildings (see Fig. 2). With respect to these typological characteristics, the building stock was mainly constituted by rammed earth and poor stone masonry of irregular fabric, however in some cases simple brick masonry walls were also found. Horizontal diaphragms and roofing structure systems are mostly composed by timber elements, although occasionally, slender reinforced concrete slabs were found. Due to difficulties encountered in accessing the interior of all the buildings and time constraints, two types of inspections with two different levels of detail were defined. Thus, the 504 buildings were divided into three groups based on the detail of the available information: the first group composed of the 99 buildings for which it was possible to perform a detailed inspection, were studied by filling in detailed checklists developed as part of the scope of this research. As is fully discussed in [16], the inspection and diagnosis checklists were structured according to the building criteria, which were defined ahead of time in a hierarchical manner. The second group was composed of 197 buildings for which only a non-detailed exterior inspection was possible. A third group composed of 208 buildings was not included in this study due to the buildings' construction characteristics
(R.C buildings), actual conservation states (rehabilitated, in ruin or demolished) and current occupation state (unoccupied).

\section{Results and discussion}

With the application of this simplified methodology integrated in a GIS tool environment, it was possible to plot a spatial mapping of urban scale outputs. The GIS application software ArcGis ${ }^{\circledR}$ 10.2 [17] adopted in this study combines geo-referenced graphical information, in which polygons represent buildings, with several features and attributes, allowing for their display, selection and search. Although this mapping processing was performed for the parishes of Seixal, Arrentela, Amora and Paio Pires, only those related to the old city centre of Seixal are herein presented.

The first result regards the mapping of the normalised fire risk index values, $F R_{I}^{*}$ (see Fig. 3). This indicator allows in a broad and spatial manner to identify more unsafe and critical building stock. Buildings classified as most vulnerable generally combine a group of the following situations: derelict and obsolete electrical installations; structural safety problems; significant fire loading due to activities developed in those buildings; lack or inoperability of fire detection means, alert and alarm systems, constrained or even inaccessible evacuation routes.

Fire risk index values under 20, mean that buildings do not present significant problems, or compromise fire risk safety situations, being satisfied in general the fire safety code pillar requirements. On the other hand, buildings presenting fire risk index values over 40 require thorough analyses and the definition of preventive measures to improve their safety conditions. Finally, a fire risk index value between 20 and 40 means that buildings do not comply with all the fire code requirements, being necessary to adapt and implement further improving measures. It is worth noting that, although they have been defined from comparative analyses with the original ARICA approach, this boundaries are indicative and therefore they should not be interpreted rigidly.

In zones $\mathrm{Z1}, \mathrm{Z} 2$ and $\mathrm{Z3}$, one can observe that several buildings show $F R_{I}{ }^{*}$ values over 40, which generally present characteristics and features that potentially aggravate fire risks. Critical buildings were identified and considered for $F R_{I}{ }^{*}$ values over 60, normally corresponding to commercial and service buildings, which often possess extremely high fire load materials, exponentially increasing the vulnerability to fire. In zones Z4 and Z5, due to their predominant and pronounced residential use, this scenario is more encouraging, with small number of buildings showing $F R_{I}^{*}$ values above 40.

With respect to the fire ignition sub-factor values, $S F_{I}$, which is a function of four partial factors from $P F_{A 1}$ to $P F_{A 4}$ (see Table 1), it is possible to globally point out that the majority of the building stock has a moderate ignition risk, being these buildings less vulnerable to fire events, since they somehow show characteristics that reduce the risk of fire ignition. However, a small number of buildings were classified with high to extremely high values of fire ignition subfactor values, due to their function type and predominant material nature, but also due to their gas and electrical installations rendering higher probabilities of fire ignition. This fact was only true for zones Z1, Z2 and Z3, corresponding to the urban areas whereas small-scaled industry prevails.

Fig. 4 shows the mapping of the fire propagation sub-factor, $S F_{P}$, which depends in its definition, on five partial factors determination, from $P F_{B 1}$ to $P F_{B 5}$ [12]. The majority of the building stock was evaluated with low propagation risk, corresponding mainly to residential buildings with low fire load. Buildings classified with moderate propagation risk are in most cases non-residential buildings with lack or deficient fire detection alert or fire alarm systems, 

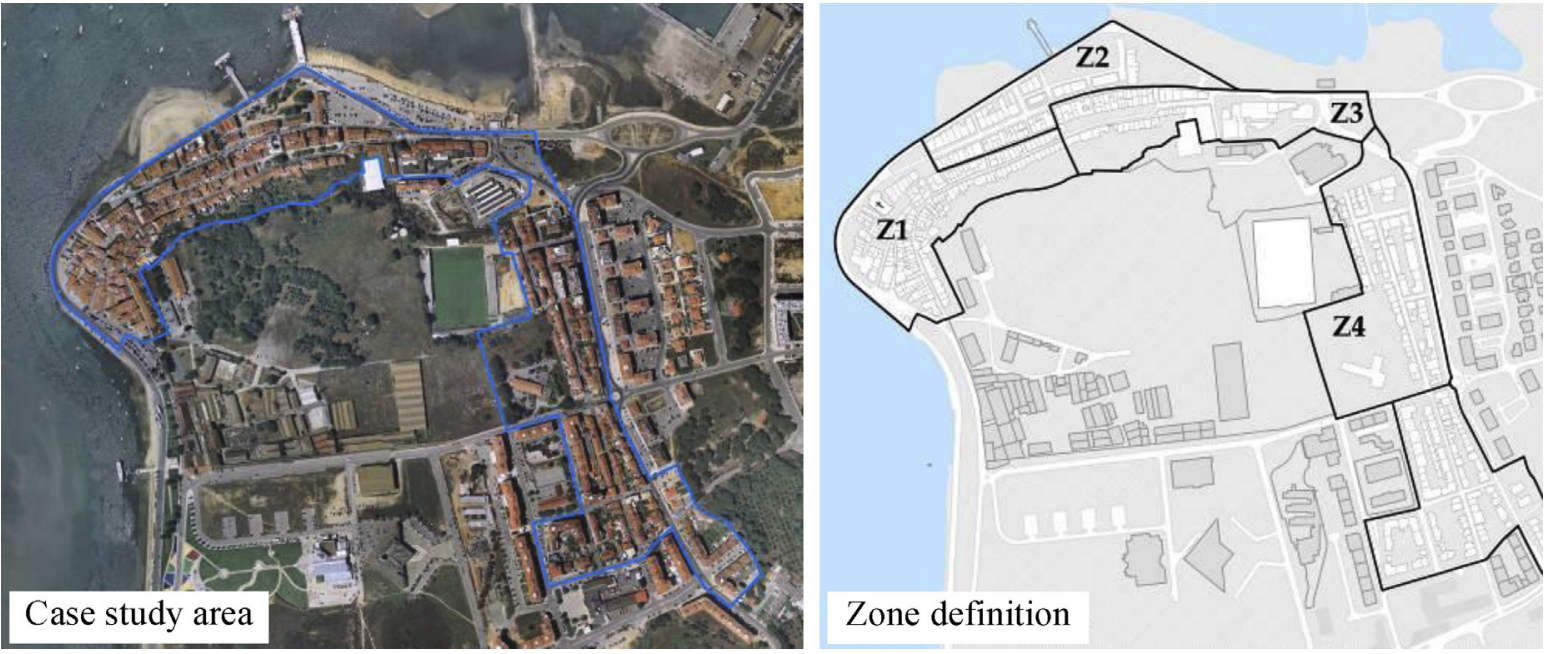

Fig. 2. Case study area of and zone delimitation, from $Z_{1}$ to $Z_{5}$.

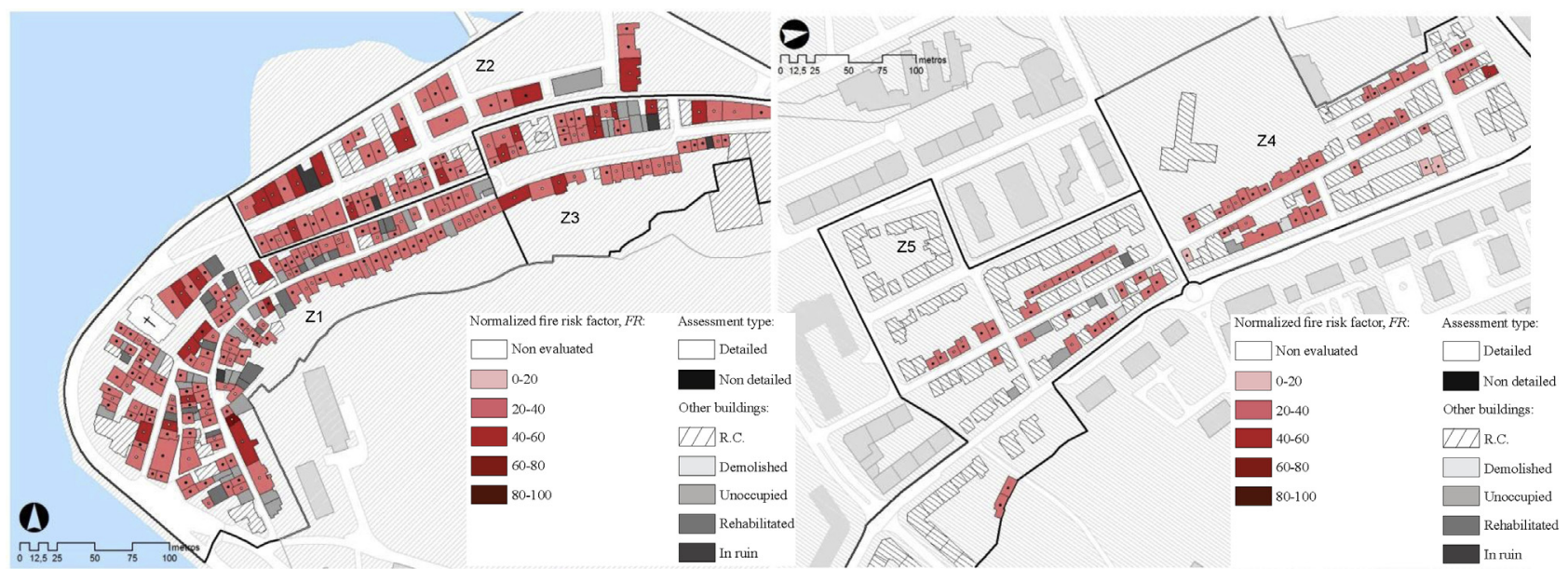

Fig. 3. Normalised fire risk, $F R_{I}{ }^{*}$, mapping for zones (a) Z1, Z2, Z3 and (b) Z4 and Z5.

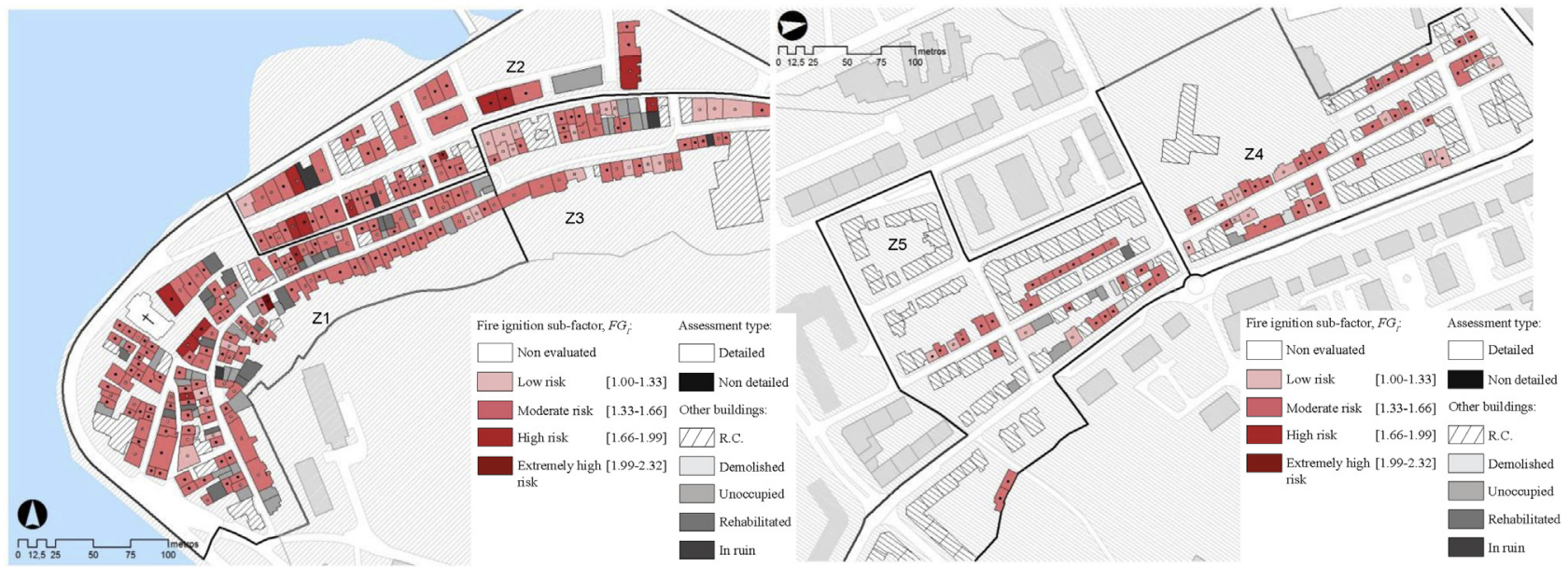

Fig. 4. Fire ignition sub-factor, $S F_{I}$, mapping for zones (a) Z1, Z2, Z3 and (b) Z4 and Z5.

with insufficiently spaced aligned openings, increasing their fire risk up to a moderate level, with focus in zones Z1, Z2 and Z3, corresponding to trade and service areas. Nightly entertainment areas of Seixal also show low values of fire risk propagation, reflecting the very favourable impact of compliance with code requirements and monitoring measures obliged by responsible entities. Only two buildings were evaluated with extremely high values of fire risk propagation, which correspond to mixed residential and commercial use buildings, whereas both stored materials and carried out activities that are potential sources of fire propagation. 


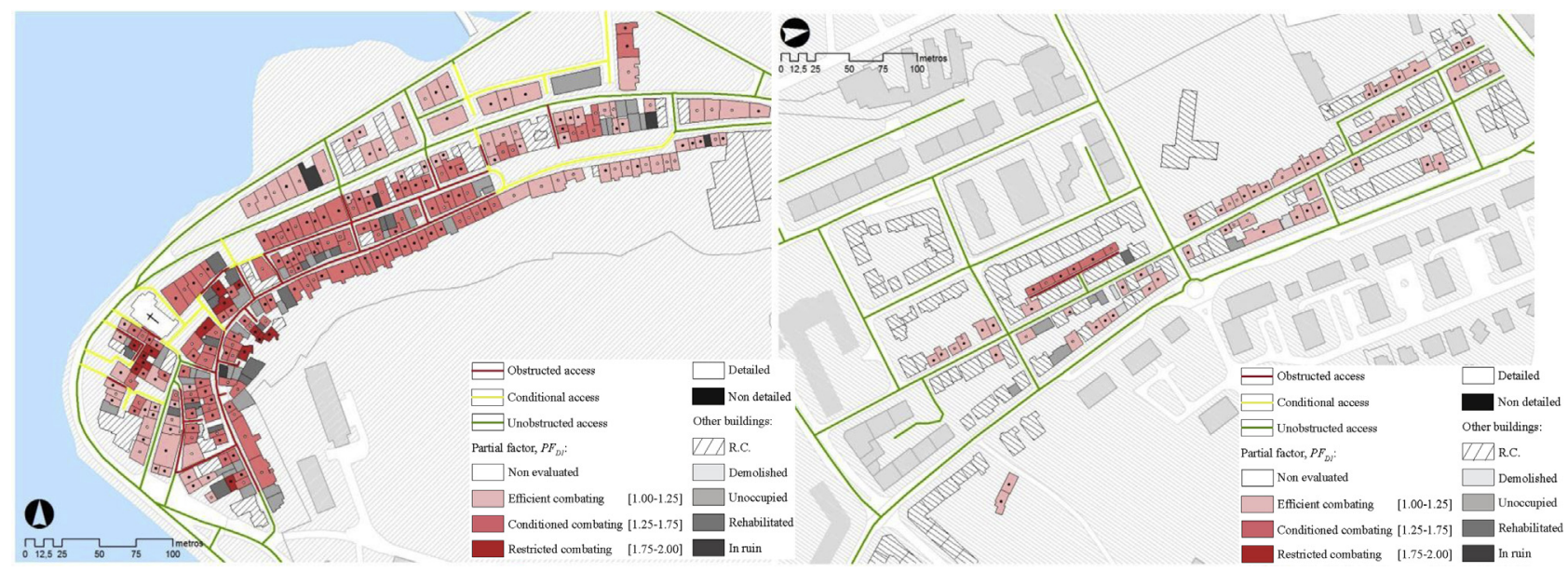

Fig. 5. Accessibility map for zones (a) Z1, Z2, Z3 and (b) Z4 and Z5.

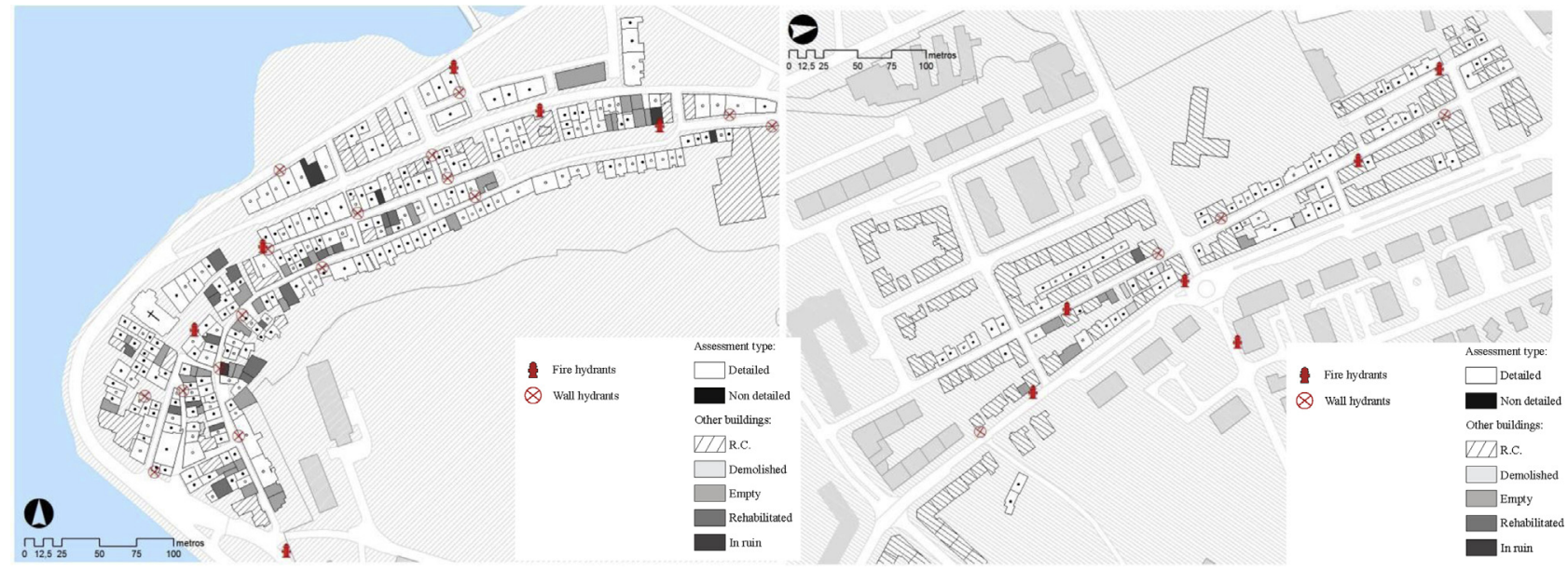

Fig. 6. Fire hydrants mapping available in zones (a) Z1, Z2, Z3 and (b) Z4 and Z5.

The results obtained for the building evacuation sub-factor, $S F_{E}$, have distinguished commercial and services buildings with the most unfavourable values in terms of fire risk evacuation. Although building evacuation can be conducted with more or less difficulty amongst the old building stock, several reasons can be pointed out as responsible for increasing evacuation time. Excluding those related with behavioural aspects, which are comprehensively discussed in [18], deficient evacuation escape routes and the configuration and efficiency of detection, alert and alarm systems, can be pointed out as the most significant ones.

External fire factors are a vital and constraining aspect of the fire fighting in old city centers, in particularly the fire hydrant location and operability and external accessibility conditions, which typically are difficult due to narrow streets and steep slopes. In zone $\mathrm{Z1}$, the presence of narrow streets, often obstructed by illegal and disorganised parking, raised by the presence of urban equipment (benches, bus stops, telephone booths) installed in strategic locations, makes this a problematic issue in terms of accessibility, affecting the fire combat response. Furthermore, inside this area there are pedestrian pathways, which makes combat using fire vehicles practically impossible. In the remaining zones, the fire combat response in general was classified as efficient, although small urban pockets need greater attention. In terms of external fire hydrants, the old city centre is well served, despite the fact of not being entirely compliant with the fire safety code.

In case of an urban fire, the accessibility conditions of competent civil protection institutions (fire brigade) are of great importance.
The spatial mapping of partial factor $P F_{D 1}$, allows plotting out the extremely important accessibility routing map (width of the streets, avenues and alleys), which is presented in a categorised manner on Fig. 5.

This accessibility route layout was based on two criteria: clear width and height, and slope. For the clear width and height of the street, it was considered as the minimum reference value, 3.5 and 4.0 meters respectively (values defined in the national fire code), taking into account obstacles, foot pathways, urban equipment. To categorise accessibility conditions, three levels were defined:

- inaccessible or possibly blocked with a width lower than $3.5 \mathrm{~m}$, or only accessible by foot (red coloured);

- partially conditioned routes (yellow coloured);

- unobstructed routes that do not offer accessibility limitations (green coloured).

It should be noted that this mapping is considered conservative and adjustable depending on the type of fire fighting vehicles for use in urban fire combat.

Aiming to evaluate the state of conservation and operability of fire hydrants, net registers were assessed by adding some missing or unregistered water service hydrants and verifying the exact location of the remaining ones. From this effort, it was possible to map Seixal's actual fire hydrants network (see Fig. 6), distinguishing both fire hydrants and wall hydrants. 
The fire safety code currently in effect requires, on the one hand, the existence of one fire hydrant at a maximum distance of 30 meters of each main building exit, and on the other hand, the existence of one wall hydrants at every 15 meters of wall. In old city centres, these requirements are not met. For this reason, in this simplified methodology, it was considered reasonable to extend the existence of fire hydrants at a maximum distance of 100 meters, independently of its type. More than the requirements in terms of the number of fire hydrants, it is fundamental that all the existing ones are working properly with adequate pressure and flow rate, which was not always assured.

\section{Conclusions}

As mentioned above, the vulnerability to fire risk in old urban areas depends on various factors, as presented as discussed previously. The method developed for the assessment of urban fire risk is based on the simplified method ARICA and was developed for large-scale assessment and operation scale, since the application of the mentioned original method to all buildings within the area studied is not possible due to time constraints issues and to the limited access conditions of the interior of buildings or on consulting drawings and details.

The results were found reliable, taking into account the scale and aim of this study, allowing the identification of the most vulnerable buildings in respect to fire risk. From the assessment carried out, it was possible to identify the main fire protection and control measures that should be implemented in the near future. The principal concerns and fire safety needs for old city centers are discussed below.

Electrical and gas installations are one of the most common fire spreading causes. The lack of information is no doubt the worst of problem. However, gas containers still continue to be conditioned in closed unventilated areas. Electrical cabling is also responsible for potential fire ignition, with the absence of electrical breakers and old electrical installations without any type of protection. In old city centres and particularly in the present case study, the existence of small commercial and service areas at the ground floor level are frequent, while upper floors are exclusively for residential purposes (mixed use of buildings), in which fire safety legal requirements are often neglected [15].

In order to reduce fire risks in the old city centre of Seixal several short and medium term measures are mentioned, such as close surveillance of unoccupied or abandoned buildings, alerting owners to the consequences in case of a fire event, improving the fire hydrants network, providing recognition measures of buildings with critical fire loads, analysing the more adequate fire combat vehicle for conditioned access locations and fire drills in critical areas within the old city centre.

The proposed methodology was validated by comparing the achieved results with those obtained applying the original ARICA (in [19]) to five buildings considered typologically representative of Seixal's building stock. Globally, although non-expressive deviations were found, the achieved results from this direct comparison can be seen as positive and satisfactory, since maximum deviations were calculated in $6 \%$. Nonetheless, further validation should be carried out, by increasing the sample size, allowing a more detailed analysis on the reliability of the proposed method.

The integration of the achieved results into a GIS tool has again proved to be a very efficient and useful strategy for data storage, namely building features and survey information, and also for the creation of risk scenarios. These features, combined with the possibility of mapping different outputs, make GIS an effective tool in the support of mitigation strategies and management of fire risk at an urban scale.
Further improvements should be implemented in the presented methodology, such as the influence of adjacent buildings with higher fire risk potential, which should naturally be considered when assessing neighbouring buildings. Moreover, uncertainty analysis and of the human factors in order provide exposure parameter definition and evacuation procedure characterization should be also addressed on further studies. Finally, as the proposed methodology is based on Portuguese fire codes and regulations, limiting its applicability to other countries, further developments should address its adaptation to European fire codes in force, so that it could be applicable and extended to other European countries.

\section{Acknowledgments}

The authors would like to acknowledge the Civil Protection Department of Seixal Municipality for their contribution and cooperation on providing adequate and up-to-date information during all the building inspection appraisal and recording activity, as well as logistic support. The anonymous reviewers are also thanked for their insightful comments and constructive suggestions.

\section{References}

[1] R. Vicente, Strategies and Methodologies for Urban Rehabilitation Interventions, Seismic Vulnerability and Risk Assessment of Coimbra's Downtown Area Building Stock (PhD Dissertation), Civil Engineering Department of the University of Aveiro, Portugal, 2008

[2] A.M.S. Fernandes, Fire Safety in Old City Centers (Master Dissertation), Faculty of Science and Technology of the University of Coimbra, Portugal, 2006 (in Portuguese).

[3] Portugal, Minesterial Order No. 426/89, Medidas cautelares de segurança contra risco de incêndio em centros urbanos antigos, Ministério da Administração Interna e das Obras Públicas, Transportes e Comunicações, Lisbon, Portugal, 1989, pp. 5309-5313

[4] A. Leça Coelho, Building conservation and rehabilitation from the point of view of fire safety, in: A.B. Coelho, J.V. Paiva (Eds.), Conservação e reabilitação de edifícios recentes, Caderno Edifícios CAD 5, first ed., LNEC, Lisbon, Portugal, 2010.

[5] A. Magalhães, Modelo Informático para a realização de Inspeções e Gestão da SCIE (Master Dissertation), Faculty of Engineering of the University of Oporto, Portugal, 2012

[6] D. Barral, Implementação do modelo FIREcheck no âmbito das medidas de autoproteção da SCIE (Master Dissertation), Faculty of Engineering of the University of Oporto, Portugal, 2013.

[7] C.F. Castro, J.B. Abrantes, Manual de Segurança contra Incêndio em Edifícios, Escola Nacional de Bombeiros, Sintra, Portugal, 2009.

[8] P. Figueiredo, Análise de risco de incêndio na baixa de Coimbra (Master Dissertation), Faculty of Science and Technology of the University of Coimbra, Portugal, 2008.

[9] J. Porto, Aplicação da Nova Regulamentação de Segurança contra Incêndio em Edifícios, A Engenharia na Proteção Civil, 2nd series, Ingenium Edições Lda, Ordem dos Engenheiros, n.116, Lisbon, Portugal, 2010, pp. 35-37 (in Portuguese).

[10] A. Leça Coelho, Metodologias de Avaliação de Risco de Incêndio Urbano, in: Seminário Núcleos Urbanos Antigo e as Estratégias de Proteção Civil, 2010

[11] F. Neves, A. Costa, R. Vicente, C.S. Oliveira, H. Varum, Seismic vulnerability assessment and characterisation of the buildings on Faial Island, Azores, Bull. Earthquake Eng. 10 (1) (2012) 27-44.

[12] R. Vicente, Cadernos de apoio ao estudo do risco sísmico e de incêndio em centros urbanos antigos do Seixal, Pedro Nuno Institute, Seixal, Portugal, 2010.

[13] Portugal, Ministerial Order No. 1532/2008, Regime Jurídico de Segurança contra Incêndios em Edifício, INCM, Lisbon, Portugal, 2008, pp. 9050-9127.

[14] A. Rodrigues, Risco de incêndio em centros históricos: índice de risco (Fire Risk in Historical Centres: Risk Index) (MSc Dissertation), Civil Engineering Department of the University of Aveiro, Portugal, 2010 (in Portuguese).

[15] Portugal, Ministerial Order No. 220/2008, "Segurança contra Incêndios em Edifícios", Official Gazette of the Republic of Portugal, 1st series, Ministerial Order No. 220. Lisbon, 2008, pp. 7903-7922 (in Portuguese).

[16] C. Santos, T.M. Ferreira, R. Vicente, J.A.R. Mendes da Silva, Building typologies identification to support risk mitigation at the urban scale-Case study of the old city centre of Seixal, Portugal, J. Cult. Herit. 14 (6) (2013) 449-463.

[17] ESRI, Geographic Information Systems (GIS), Environmental Systems Research Institute. 310 New York Street, Redlands, 92373-8100, USA, 2005.

[18] G. Proulx, Movement of People: the Evacuation Timing. The SFPE Handbook of Fire Protection Engineering, fourth ed., National Fire Protection Association, Quincy, 2008

[19] A. Rodrigues, Risco de incêndio em centros históricos: índice de risco (Master Dissertation), University of Aveiro, Portugal, 2010. 